\title{
A TELJESÍTMÉNYMÉRÉS MÓDSZEREI A KKV SZEKTORBAN
}

\author{
Dajnoki Krisztina - Filep Roland
}

\begin{abstract}
Absztrakt: A teljesítménymérés kérdésköre régóta foglalkoztatja a kutatókat, számos munka születik a témában. Jelen tanulmány célja egyrészt a szakirodalomban leggyakrabban előforduló teljesítménymutatók feltárása, másrészt pedig a mérési módszereknek a tanulmányozása volt. Mivel a kézirat egy szélesebb körü kutatásnak egy részét képezi, ezért teljesítmény-mutatók tekintetében azokra helyeztük a fókuszt, amelyeket a KKV-k körében olyan társadalomtudományi kutatásokban használnak, mint a vezetési stílus, a vállalkozói készségek és a változásmenedzselési szokások szervezet összteljesítményére gyakorolt hatásának vizsgálata. A mutatóknak többféle csoportosítása létezik, amelyek közül az egyik leggyakoribb a pénzügyi és a nem pénzügyi mutatók elkülönítése. Az utóbbit elsősorban a nagyvállalatok alkalmazzák, de ők is csak a pénzügyi mutatók használata mellett teszik ezt. Széleskörü szakirodalmi feldolgozás alapján pénzügyi mutatók tekintetében az eredményesség és a forgalom (árbevétel), nem-pénzügyi esetben pedig a vevői- és a dolgozóielégedettség mutatók voltak a leggyakoribbak. A KKV-k vizsgálatánál jellemzően pénzügyi mutatókat alkalmaznak, ezen belül objektív és szubjektív mérési módszereket különböztetnek meg a kutatók. Az objektívek azonos számviteli szabályok szerint készülnek, viszont az adózás miatt manipuláltak lehetnek és az iparági összehasonlításokat is megnehezítik, ezért már évtizedekkel ezelött is vizsgálták a teljesítmény mérésének szubjektív lehetőségét, amelyek kiküszöbölhetik ezeket a hátrányokat. Új mérési módszereket fejlesztettek ki és alkalmaztak empirikus kutatásokban. A hátrányuk, hogy kizárólag megkérdezés útján juthatunk hozzá az adatokhoz, viszont statisztikai módszerekkel végzett vizsgálatok alapján magas korrelációs értékeket mutatnak az objektív módszerekkel, azokkal egyenértékünek tekinthetők, így a szubjektív megközelítések biztonsággal alkalmazhatók kutatásokban. A 2010-es évekből származó kéziratok további kutatási javaslatként nevezik meg a szubjektív mérést lehetővé tevő kérdőívek további empirikus tesztelését, hogy a fent említett számviteli és iparági sajátosságoknak a kiküszöbölésével minél megbízhatóbb méréseket végezhessünk.
\end{abstract}

Abstract: The issue of performance measurement has been of concern to researchers for a long time, and much work is being done on the topic. The aim of the present study was to explore the most common performance indicators in the literature and to study the measurement methods. As the manuscript is part of a broader body of research, we have focused on performance indicators for those used in social science research among SMEs, such as examining the impact of leadership style, entrepreneurial skills, and change management habits on an organization's overall performance. There are several groupings of indicators, one of the most common being the separation of financial and non-financial indicators. The latter is used primarily by large corporations, but they also do so only with the use of financial indicators. Based on extensive literature review, performance and turnover (sales revenue) indicators were the most common in terms of financial indicators, and customer and employee satisfaction indicators were the most common in the case of non-financial cases. Financial indicators are typically used in the study of SMEs, within which researchers distinguish between objective and subjective measurement methods. Lenses are made according to the same accounting rules, but they can be manipulated due to taxation and also make industry comparisons difficult, so the subjective possibility of measuring performance, which can eliminate these disadvantages, has been explored for decades. New measurement methods have been developed and applied in empirical research. Their disadvantage is that we can only access the data through questioning, but based on studies with statistical methods, they show high correlation values with objective methods, they can be considered equivalent, so subjective approaches can be safely applied in research. Manuscripts from the 2010s mention further empirical testing of subjective measurement questionnaires as a further research proposal in order to make the most reliable measurements possible by eliminating the accounting and industry specificities mentioned above.

DOI: $10.14232 /$ jtgf.2020.3-4.55-64 
Kulcsszavak: teljesítmény, mérési módszerek, szubjektív mérés, objektív mérés, leadership, KKV

Keywords: performance, measurement methods, subjective measurement, objective measurement, leadership, SMEs

\section{Bevezetés}

A teljesítmény mérésének kérdésköre a kutatókat és az üzleti élet szereplöit is különösen foglalkoztatja. A szervezeti teljesítmény fogalmára vonatkozóan több meghatározás létezik. Smith és Reece (1999) tágabb értelemben definiálja azt és úgy fogalmaz, hogy annak a képességét jelenti, ahogyan a szervezet a tulajdonosainak az elképzeléseit, várakozásait kielégíti és hangsúlyozza, hogy ezt a produktivitást időről-időre mérni kell.

A mérésnél különböző objektív és szubjektív módszereket alkalmaznak a kutatók. Ebben a munkánkban a teljesítmény definícióinak általános áttekintését követően részletesebben térünk ki azokra a mutatókra, amelyek a KKV-k esetén a leggyakrabban fordulnak elö. A tanulmányban a fókuszt azokra a mutatókra helyezzük, amelyek a leadership elméletek teljesítményre gyakorolt hatásának vizsgálatánál legújabban alkalmazottak. (Megalapozva ezzel a további kutatómunkánkat, ami a vezetési stílus, a változásmenedzselés és a szervezeti teljesítmény kapcsolatának vizsgálatára irányul.) Zulkiffli és Perera (2011) azt hangsúlyozza, hogy az objektív mérési módok mellett a társadalomtudományok területén már átfogóan alkalmazott szubjektív módszerek megfelelő alternatívát jelentenek, de ezek további fejlesztésére és empirikus tesztelésére van szükség. A kutatómunkánk zárásaként az áttekintett szakirodalom után a vezetői tevékenység szervezeti teljesítményre gyakorolt hatásának mérésére használt kérdőíveket és empirikus vizsgálatokat vetjük össze egymással.

Kutatási kérdéseink $(\mathrm{K} 1, \mathrm{~K} 2)$ a következők:

- K1: Melyek a leggyakrabban használt mutatók a szervezeti teljesítmény mérésére KKV-k esetén?

- K2: Milyen új megközelítéseket, módszereket használnak a teljesítményadatok felvételére?

\section{Teljesítmény}

A szervezeti teljesítményre vonatkozóan a Smith és Reece (1999) által megfogalmazott tág értelmezés mellett további definíciók is napvilágot láttak az elmúlt évtizedekben. Laitinen (2002) alapján általában a teljesítmény arra utal, hogy a szervezet vagy egy alegység képes eredményeket elérni olyan mértékben, amelyeket előre meghatároztak. Ho (2008) a teljesítményt egy olyan mérőszámnak tekinti, amely megmutatja, hogy egy szervezet mennyire megfelelő mértékben realizálja a céljait, Fenyves et al. (2018) alapján a vezetők óriási nyomás alatt vannak, hogy a szervezet ténylegesen elérje ezt a célteljesítményt.

Lusthause et al. (2002) négy, Richard et al. (2009) három különböző dimenziót különítenek el ahhoz, hogy definiálják a szervezeti teljesítményt. Előbbi specifikus területként, utóbbi kulcsfontosságú elemként nevesíti őket. A Szerzők munkáját az alábbi 1. táblázat elkészítésével, kulcs dimenziók létrehozásával hasonlítottuk össze. 


\section{1. táblázat: Szervezeti teljesítmény kulcs dimenziói}

\begin{tabular}{|l|l|l|}
\hline Kulcs dimenziók & (A) Lusthause et. al. & (B) Richard et al. \\
\hline 1. pénzügy & pénzügyi életképesség & pénzügyi teljesítmény \\
\hline 2. termék / szolgáltatás & hatékonyság & termékpiac teljesítmény \\
\hline 3. értintettek & folyamatos relevancia & részvényesi visszatérítés \\
\hline $\begin{array}{l}\text { 4. össz-szervezeti } \\
\text { érdekek }\end{array}$ & hatásosság & - \\
\hline
\end{tabular}

Forrás: Saját szerkesztés Richard et al. (2009), Lusthause et al. (2002) alapján

Az alábbiakban az 1. táblázatban szereplő dimenziók mentén történik az (A) Lusthause et al. és a (B) Richard et al. által megfogalmazottaknak az összevetése.

(1.) pénzügy tekintetében (A) esetben a szervezetnél az a lényeges, hogy a pénzügyi források befolyása nagyobb legyen azok kiáramlásánál, (B) esetén a profit, a ROA és a ROI tartoznak ehhez a dimenzióhoz.

A (2.) termék / szolgáltatás dimenziónál (A) esetben mennyire gazdaságosan tudja a szervezet az erőforrásokat eredményessé tenni, (B) az értékesítési volumen és a piaci részesedést tartja fontosnak.

A (3.) érintetteknél (A)-nál alkalmazkodni kell az érintettekhez és a környezethez, (B) esetben a gazdasági hozzáadott érték mellett a részvényesi hozam kerül fókuszba.

A (4.) esetben (A) a teljes szervezetre nézve fogalmazza meg azt, hogy meg kell vizsgálni mennyire képes elérni a célját, (B) ilyen tekintetben nem tesz megállapításokat.

A fentiekből látható, hogy Lusthause et al. (2002) általánosabban, Richard et al. (2009) pedig konkrétabban fogalmaznak ezeket a specifikus területeket / kulcsfontosságú elemeket illetően. Vannak olyan teljesítménymutatók, amelyek például egy konkrét termék gyártásához kapcsolódnak és olyanok is, amelyeknél az össztermék gyártásának és egyéb tényezők figyelembe vételének az eredőjeként kapjuk meg a vállalkozás végső teljesítményét. Ebben a munkánkban teljesítmény tekintetében ezzel az utóbbival foglalkozunk, vagyis a vállalkozás aktuális, egy évre vetített összteljesítményével.

A teljesítménymutatóknál többféle csoportosítás létezik, ezek közül a nem pénzügyi és a pénzügyi, ez utóbbin belül pedig az objektív és a szubjektív mérési módokat mutatjuk be.

\section{Anyag és módszer}

Az alábbiakban előbb azt szemléltetjük, hogy KKV-k esetén jellemzően milyen mérési módszereket alkalmaznak empirikus vizsgálataikban a kutatók, majd az általuk a leadership/vállalkozói készségek felmérése esetén a statisztikai vizsgálatoknál a teljesítmény mérésére használt eszközök néhány példáját mutatjuk 
be, kiválasztva azt a módszert, amely a bevezetésben részletezett későbbi komplex kutatásunknál hasznos lehet.

\subsection{Teljesítmény mérése}

Gergely (2016) szerint a teljesítménymérés egy részét képezi annak a folyamatnak, amelynek célja a kitüzött eredmények elérésének a biztosítása. A kkv szektor teljesítménymérésének lehetőségeivel több nemzetközi kutatás foglalkozott (Wu, 2009; Ankrah-Mensah, 2015; Maduekwe-Karnala, 2016; Waśniewski, 2017, Kotane-Kuzmina-Merlino, 2017; Rojas-Lema et al., 2020). Chong (2008) alapján a szervezeti teljesítmény pénzügyi vagy nem pénzügyi mutatók segítségével is mérhető, amelyet a 3.1.1. pontban részletezünk. A 3.1.2. pont tartalmazza annak leírását, hogy a teljesítmény adatok forrása alapján objektív vagy szubjektív módszert különböztethetünk meg egymástól (Trailer et al., 1996).

\subsubsection{Pénzügyi vagy nem pénzügyi mutatók}

A szakirodalomban leggyakrabban használt módszerek áttekintéséhez segítségül hívtuk Mahmudova és Katonáné (2018) aktuális munkáját, akik az Emerald Insight, az Elsevier és a Google Scholar adatbázisaiban szereplö 1991 és 2018 közötti, teljesítmény mérésével kapcsolatos cikkeket tekintették át. A pénzügyi indikátoroknak összesen 120 előfordulásából 15 különböző mutatót tártak fel és közöltek, ezeket 5 fö csoportba rendeztünk, amelyet az alábbi ábra szemléltet ( 1 . $a ́ b r a)$. Ezek közül az eredmény és a forgalom-mutatók fordultak elő a leggyakrabban.

\section{1. ábra: Pénzügyi mutatók öt csoportja}

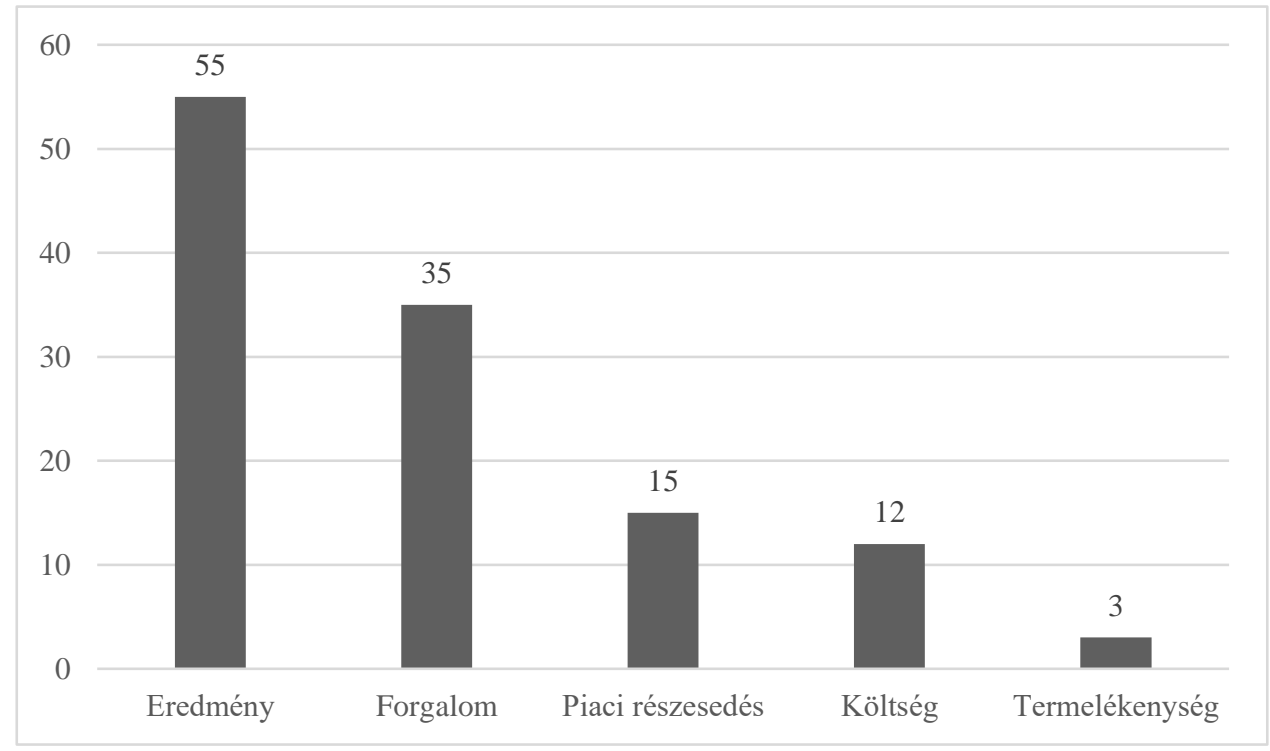

Forrás: Saját szerkesztés Mahmudova és Katonáné (2018) alapján

Carton és Hofer (2006) 1996 és 2001 között Amerikában publikált empirikus vizsgálatok tanulmányázásával hasonló eredményre jutott, a négy leggyakrabban 
használt indikátor közül kettőt az eredmény és a forgalom vizsgálata jelentette. A magyar KKV szektor szereplöi a válság okozta teljesítménybéli változásokat elsősorban a forgalom alakulásában mérték, az árbevétel növekedését vagy csökkenését vették alapul (Szabó-Farkas, 2011). A ,forgalom”, mint indikátor $a z, 1$. ábrán szereplő módon a második leggyakrabban előforduló volt a Mahmudova és Katonáné (2018)által széles körben elvégzett nemzetközi irodalom feldolgozás eredményei alapján.

A nem pénzügyi mutatókat vizsgálva az egyedi jellegükböl adódóan Mahmudova és Katonáné (2018) által közzétett adatokból nem lehet a pénzügyi mutatókhoz hasonló, egymástól elkülönülő csoportokat létrehozni. A listavezető első két helyen végzett indikátor az elégedettség vizsgálatához kapcsolódott. A nem pénzügyi mutatók összes 83 előfordulásból 14-gyel a vevői-, 9-cel a dolgozói elégedettség végzett az első, illetve a második helyen. Kiss és Barizsné (2018) vizsgálata a munkahelyi elégedettség és a szakmai illeszkedés között pozitív kapcsolatot tárt fel. A környezeti kihívásoknak való megfelelés érdekében Dajnoki et al. (2015) szerint a szervezet szempontjából is elengedhetetlenül fontos, hogy minden szakterületen megfelelően képzett munkaerő kerüljön alkalmazásra. A szakmai illeszkedés tehát kölcsönös elönyökkel jár.

Több szerző szerint (Miron et al., 2004; Brockman és Morgan, 2003; Auken et al., 2008) a nem pénzügyi mutatók vizsgálata a jobb megoldás, mivel a számviteli megközelítések (pénzügyi mutatók) múltbeli történetiségen alapulnak és nem tükrözik a jövőt. Wall et al. (2004), valamint Quinn és Rohrbaugh (1981) különböző faktorok vizsgálatával mérik a teljesítményt úgy, mint emberi kapcsolatok, belső folyamatok, a szervezeti nyitottságára vonatkozó adatok. Zulkiffli és Perera (2011) alapján a pénzügyi mutatók előnye, hogy auditáltak, azonos szabályrendszer alapján készülnek. A nem pénzügyi mutatókról általánosságban elmondható, hogy mivel nem függetlenek a vállalkozás tevékenységétől, iparágától és akár vállalkozások szintjén is egyediek lehetnek, ezért nehezen összehasonlíthatók.

A szervezetek mérete befolyással van az alkalmazott teljesítménymutatók jellegére, vagyis a KKV-k és a nagyvállalatok az azonosak mellett egymástól eltérö módszereket is használnak (Speckbacher et al., 2003). Malina és Selto (2004) kutatása alapján inkább a nagyvállalatokra jellemző a nem pénzügyi mutatók használata, amelyek előszeretettel alkalmazzák mindkét típust.

A mutatókat mérési mód alapján is csoportosíthatjuk, amelyet a következő alfejezet tartalmaz. Mivel a KKV-k körében a fentiek alapján jellemzően pénzügyi mutatókat (Malina-Selto, 2004) használnak és ebben a munkánkban ezek a szervezetek jelentik a célcsoportunkat, ezért a továbbiakban (3.1.2. alfejezet) kizárólag a pénzügyi mutatókra vonatkozóan vizsgáljuk azok objektív vagy szubjektív technikával történő felvételének irodalmát.

\subsubsection{Objektív vagy szubjektív mérési mód}

Az objektív mérési módok tényadatokon alapulnak (Vorhies és Morgan, 2003). A profitban lehet 1-1 termékfejlesztés miatti visszaesés is, ezért érdemes kidolgozott mérési rendszerrel 1-1 mérést konkrét iparágakra elvégezni (Covin-Slevin, 1989; 
Dawes, 1999), ezért arra tesznek javaslatot (Covin-Slevin, 1989), hogy a kutatók dolgozzanak ki efféle mérési módszereket.

A szubjektív mérési módoknak olyan vélekedések és becslések képzik az alapját, amelyet az adott szervezet vezetői vagy az információ birtokosai tesznek (Covin et al., 1990), tehát szabadon nem hozzáférhető adatokat jelentenek, amelyek csak rákérdezés útján szerezhetők be. Dess és Robinson (1984) empirikus vizsgálatával, korrelációs statisztikai módszert alkalmazva mutat rá arra, hogy a szubjektív mérési módszerek az objektívekkel egyenértékünek tekinthetők, értékesítési forgalom és ROA esetében is 0,80-hoz közeli volt a korreláció értéke (azaz hihetünk a válaszadóknak). További mérések (Dawes 1999; Wall et al. 2004; Song et al., 2005; Gruber et al., 2010) esetén is magas korrelációs értékek mutatkoztak.

Gruber et al. (2010) alapján nehézségeket okozhat az objektív adatok vizsgálatnál az, hogy az adóelkerülésből származó esetleges manipuláció miatt nem tükrözik a valóságot, sok vezető nem is akarja nyilvánosságra hozni ezeket az adatokat így teljesebb információt szolgáltatnak a szubjektív mérési módok. A legfőbb pénzügyi sarokszámok (nettó árbevétel, adózott eredmény, mérlegföösszeg) nyilvános adatbázisokból is szabadon elérhetők így a megkérdezés útján kapott adatokkal könnyen összehasonlíthatók. Ugyancsak problémát jelent a különböző ágazatokban müködő szervezetek összevetése. Dess és Robinson (1984) empirikus kutatásukban mérőszámként használt ROA (eszközök hozama) mutató alapvetően ugyanazon az ágazaton belül müködő vállalatok esetében alkalmazható összehasonlításra (Zéman-Béhm, 2016), de mivel szubjektív adatfelvételi módot is választottak, így kivitelezhetővé vált az egymáshoz való viszonyítás. Song et al. (2005) szerint ugyanis ez a fajta adatfelvételi mód iparágtól, időhorizonttól, kulturális és gazdasági körülményektől függetlenül alkalmas az összehasonlításra, mivel az iparág teljesítményéhez tudják így viszonyítani a sajátjukat. Az objektív mutatók iparágtól függően változhatnak, és ezzel elrejthetik, elfedhetik a független változók és a teljesítmény (mint függő változó) kapcsolatát (Dawes, 1999). A szubjektív adatoknak is megvan a hátránya, mégpedig a hozzáférhetőség, mivel nyilvános adatbázisokból nem érhetők el, rákérdezés szükséges hozzá. A következő fejezet tartalmazza azt, hogy milyen formában, milyen konkrét kérdésekkel mérik fel a kutatók ezeket a teljesítmény adatokat.

\subsection{Kérdőívek tartalma}

A 2. táblázatban foglaltuk össze azt, hogy milyen egyezöségek, illetve különbözőségek tapasztalhatók az egyes kutatók szubjektív teljesítmény méréséhez használt kérdőívei között.

A kérdőívek vizsgálatánál is visszaigazolódtak azok az elméleti fejezetben bemutatott statisztikák, amely szerint az árbevétel és a profit népszerü teljesítménymutatókat jelentenek a kutatók körében. Az összteljesítmény és a piaci részesedés is megjelenik legalább három-három kutatás esetén. 
2. táblázat: Kérdő́vek összevetése

\begin{tabular}{|l|c|c|c|c|}
\hline $\begin{array}{l}\text { Kérdések mire } \\
\text { vonatkoznak? }\end{array}$ & $\begin{array}{c}\text { Dess és } \\
\text { Robinson } \\
(\mathbf{1 9 8 4 )}\end{array}$ & $\begin{array}{c}\text { Zulkiffi } \\
\mathbf{( 2 0 1 1 )}\end{array}$ & $\begin{array}{c}\text { Arham } \\
\mathbf{( 2 0 1 4 )}\end{array}$ & $\begin{array}{c}\text { Sulaiman } \\
\text { (2016) }\end{array}$ \\
\hline Árbevétel & $\begin{array}{c}\text { Árbevétel } \\
\text { növelés }\end{array}$ & Árbevétel & $\begin{array}{c}\text { Árbevétel } \\
\text { növekedés }\end{array}$ & $\begin{array}{c}\text { Árbevétel } \\
\text { növekedés }\end{array}$ \\
\hline Profit/eredmény & ROA & - & ROS & általánosan \\
\hline $\begin{array}{l}\text { Összteljesítmény } \\
\text { siker }\end{array}$ & általánosan & - & ROI & ROI \\
\hline Piaci részesedés & - & Részesedés \\
növekedése & $\begin{array}{c}\text { Részesedés } \\
\text { növekedése }\end{array}$ & $\begin{array}{c}\text { Részesedés } \\
\text { növekedése }\end{array}$ \\
\hline Időhorizont & $\begin{array}{c}\text { elmúlt öt év } \\
\text { átlaga }\end{array}$ & aktuális év & aktuális év & $\begin{array}{c}\text { elmúlt három } \\
\text { év }\end{array}$ \\
\hline Viszonyítás & $\begin{array}{c}\text { hasonló } \\
\text { értékesítési } \\
\text { volumenú } \\
\text { cégek az } \\
\text { iparágban és } \\
\text { a régióban }\end{array}$ & for iparági & átlagos \\
versenytásak & $\begin{array}{c}\text { versenytársak } \\
\text { versenytársak }\end{array}$ & & & 7 \\
\hline Skála fokszáma & 5 & 7 & 5 & \\
\hline
\end{tabular}

Forrás: Saját szerkesztés

Időhorizont tekintetében a kérdőívek fele az aktuális évre kérdez, a másik fele viszont az elmúlt három, illetve öt év adatait vizsgálja. A vizsgált kérdőívek egyik fele 5, másik fele 7 pontos Likert formátumú értékelőskálát használt. A minta méretét illetően Roscoe (1975) szerint egy statisztikai vizsgálathoz 30 és 500 közötti nagyságú mintára van szükség. Hair et al. (2014) minimum 100-ban határozzák meg ezt a nagyságot.

\section{Eredmények}

A K1 kutatási kérdés vizsgálatánál az 1-es fejezet elméleti áttekintése azt mutatja, hogy a teljesítmény mérésére használt indikátorokat jellemzően két különböző csoportba sorolják a kutatók, megkülönböztetnek pénzügyi vagy nem pénzügyi mutatókat. Az előbbiek előnye, hogy a legtöbb esetben számviteli adatokon alapulnak, amelyek akár nyilvános adatbázisokból is elérhetőek, vagy a belőlük kalkulálható viszonyszámok, viszont a hátrányuk az, hogy nem tükrözik a jövőt. A nem pénzügyi mutatók ugyan jövő orientáltak, de inkább a nagyvállalatok használják ezeket és azok sem hagyják el a pénzügyi mutatók vizsgálatát, azok mellett teszik. Heterogének, csoportosítani is nehéz őket, szervezetről szervezetre mások lehetnek, nehézkes az összehasonlítás.

A K2 kutatási kérdés megválaszolásánál fontos a 3.1.2. pontban írtakat figyelembe venni, azaz az objektív módszerek mellett egyre inkább előtérbe kerülnek új megoldásként a szubjektívek. Ez utóbbiak a bemutatott empirikus vizsgálatok alapján erős korrelációban állnak az objektívekkel, ezért lehet bízni abban, amit rákérdezés útján nyerhetünk és további előnyük, hogy az esetleges 
számviteli finomságokat kiküszöbölik és iparágon belül jobb összehasonlíthatóságra adnak lehetőséget.

\section{Következtetések}

Az eredmények fejezetben leírtakból következik, hogy KKV-k vizsgálatánál a szakirodalom alapján a gyakorlatban inkább a pénzügyi mutatók használatát javasolják. Ezen belül az objektív mérési mód mellett az előnyei miatt szubjektív módon felvett adatokkal is érdemes összehasonlításokat végezni, amelyet napjainkban a társadalomtudományok területén egyre gyakrabban alkalmaznak.

További kutatási irányként határozható meg annak vizsgálata, hogy a jellemzően nagyvállalatok körében használt nem pénzügyi mutatók mérésével kapcsolatban milyen tapasztalatokkal rendelkeznek azok a KKV-k, amelyek a pénzügyi mutatók mellett ilyen méréseket (pl. vevő, dolgozó elégedettség) is végeznek. A nem pénzügyi mutatók vizsgálata a jövő orientáltságból adódóan előnyös lehet a kisebb méretü szervezetek részére is.

A kutatás egy szélesebb spektrumot felölelő munka részét képezi. A későbbiekben a vezetési stílus, változásmenedzselés és szervezeti teljesítmény kapcsolatának vizsgálatánál jelen kutatás keretében feltárt kulcs teljesítmény kérdések a később összeállításra kerülő kérdőív egyik blokkját képezik majd.

\section{Köszönetnyilvánítás}

A publikáció EFOP3.6.3-VEKOP-16-2017-00007-"Tehetségből fiatal kutató" - A kutatói életpályát támogató tevékenységek a felsőoktatásban projekt támogatásával készült.

\section{Irodalomjegyzék}

Ankrah, E., Mensah, C.C.Y. (2015): Measuring Performance in Small and Medium Scale Enterprises in the Manufacturing Industry in Ghana. International Journal of Research in Business Studies and Management, 2 (12): 34-43. ISSN 2394-5923 (Print) \& ISSN 2394-5931 (Online)

Auken, H. Van, Madrid-Guijarro, A., Garcia-Perez-De-Lema, D., Van Auken, H., García-Pérez-DeLema, D. (2008): Innovation and SME Performance in Spanish Manufacturing Firms Value, fair value and ethic View project Financiación a la PYME mexicana View project Innovation and performance in Spanish manufacturing SMEs. Article in International Journal of Entrepreneurship and Innovation Management, 8 (1): 36-56. https://doi.org/10.1504/IJEIM.2008.018611

Brockman, B. K., Morgan, R. M. (2003): The Role of Existing Knowledge in New Product Innovativeness and Performance. Decision Sciences, $34 \quad$ (2): 385-419. https://doi.org/10.1111/1540-5915.02326

Carton, R. B., Hofer, C. W. (2006): Measuring organizational performance: Metrics for entrepreneurship and strategic management research. Edward Elgar Publishing, Cheltenham.

Chong, H. (2008): Measuring performance of small-and-medium sized enterprises: the grounded theory approach. Journal of Business and Public Affairs, 2 (1): 1-10.

Covin, J. G., Prescott, J. E., Slevin, D. P. (1990): The Effects Of Technological Sophistication On Strategic Profiles, Structure And Firm Performance. Journal of Management Studies, 27 (5): 485-510. https://doi.org/10.1111/j.1467-6486.1990.tb00258.x 
Covin, J. G., Slevin, D. P. (1989): Strategic management of small firms in hostile and benign environments. Strategic Management Journal, $10 \quad$ (1): 75-87. https://doi.org/10.1002/smj.4250100107

Dajnoki, K., Pierog, A., Vörös, P. (2015): Képzési-fejlesztési lehetőségek eredményességének megítélése megváltozott munkaképességű személyeket foglalkoztató szervezeteknél. Acta Scientiarum Socialium, Volume 43: 57-66.

Dawes, J. (1999): The Relationship between Subjective and Objective Company Performance Measures in Market Orientation Research: Further Empirical Evidence. Marketing Bulletin 10: $65-75$.

Dess, G. G., Robinson Jr., R. B. (1984): Measuring Organizational Performance in the Absence of Objective Measures: The Case of the Privately-Held Firm and Conglomerate Business Unit Author. Strategic Management Journal, 5 (3): 265-273. https://doi.org/10.1002/smj.4250050306

Fenyves, V., Bács, Z., Karnai, L., Nagy, A., Tarnóczi, T. (2018): Financial performance measurement of Hungarian retail food companies. Contemporary Economics, 12 (4): 459-472. https://doi.org/10.5709/ce.1897-9254.290

Gergely, É. (2016): A teljesítménymenedzsment funkcionális jellege Functional character of the performance management. Journal, International Sciences, Management Gazdas, Debreceni Egyetem Vezet, Kar, 1 (1): 1-14. https://doi.org/10.21791/IJEMS.2016.1.20.A

Gruber, M., Heinemann, F., Brettel, M., Hungeling, S. (2010): Configurations of resources and capabilities and their performance implications: an exploratory study on technology ventures. Strategic Management Journal, 31 (12): 1337-1356. https://doi.org/10.1002/smj.865

Hair, J. F., Black, W. C., Babin, B. J., Anderson, R. E. (2014): Multivariate Data Analysis (7th Edition). Prentice Hall, Indian International.

Ho, L. A. (2008): What affects organizational performance? the linking of learning and knowledge management. Industrial Management and Data Systems, 108 (9): 1234-1254. https://doi.org/10.1108/02635570810914919

Kiss, Z., Barizsné, H. E. (2018): A munkahelyi elégedettség és a szakmai illeszkedés kapcsolata fiatal diplomások körében. In: Tóth, Dorina Anna (Szerk.) Az Oktatás Gazdagsága : Tanulmányok Polónyi István Tiszteletére. Debreceni Egyetem, Debrecen, 81-94.

Laitinen, E. K. (2002): A dynamic performance measurement system: Evidence from small Finnish technology companies. Scandinavian Journal of Management, 18 (1): 65-99. https://doi.org/10.1016/S0956-5221(00)00021-X

Kotane, I., Kuzmina-Merlino, I. (2017): Analysis of Small and Medium Sized Enterprises' Business Performance Evaluation Practice at Transportation and Storage Services Sector in Latvia. Procedia Engineering. 178: 182-191. https://doi.org/10.1016/j.proeng.2017.01.093

Lusthaus, C., Adrien, M.-H., Anderson, G., Carden, F., Montalván, G. (2002): Organizational Assessment: A Framework for Improving Performance. IDB, IDRC, Washington D.C.

Maduekwe, C.C., Karnala, P. (2016): Performance measurement by small and medium enterprises in Cape Metropolis, South Africa. Problems and Perspectives in Management, 14 (2): 46-55.

Mahmudova, L., Katonáné Kovács, J. (2018): Definitining the Performance of Small and Medium Enterprises. Network Intelligence Studies, 6 (12): 111-120.

Malina, M. A., Selto, F. H. (2004): Choice and change of measures in performance measurement models. Management Accounting Research, 15 (4): 441-469. https://doi.org/10.1016/j.mar.2004.08.002

Miron, E., Erez, M., Naveh, E. (2004): Do personal characteristics and cultural values that promote innovation, quality, and efficiency compete or complement each other? Journal of Organizational Behavior, 25: 175-199. https://doi.org/10.1002/job.237

Quinn, R. E., Rohrbaugh, J. (1981): A Competing Values Approach to Organizational Effectiveness. Public Productivity Review, 5 (2): 122-140. https://doi.org/10.2307/3380029

Richard, P. J., Devinney, T. M., Yip, G. S., Johnson, G. (2009): Measuring Organizational Performance: Towards Methodological Best Practice. Journal of Management, 35 (3): 718-804. https://doi.org/10.1177/0149206308330560 
Rojas-Lema, X., Alfaro-Saiz, J-J., Rodríguez-Rodríguez, R., Verdecho, M.-J. (2020): Performance measurement in SMEs: systematic literature review and research directions, Total Quality Management \& Business Excellence, https://doi.org/10.1080/14783363.2020.1774357

Roscoe, J. T. (1975): Fundamental research statistics for the behavioural sciences. Holt Rinehart \& Winston, New York.

Smith, T. M., Reece, J. S. (1999): The relationship of strategy, fit, productivity, and business performance in a services setting; The relationship of strategy, fit, productivity, and business performance in a services setting. Journal of Operations Management, 17: 145-161. https://doi.org/10.1016/S0272-6963(98)00037-0

Song, M., Droge, C., Hanvanich, S., Calantone, R. (2005): Marketing and technology resource complementarity: An analysis of their interaction effect in two environmental contexts. Strategic Management Journal, 26 (3): 259-276. https://doi.org/10.1002/smj.450

Speckbacher, G., Bischof, J., Pfeiffer, T. (2003): A descriptive analysis on the implementation of Balanced Scorecards in German-speaking countries. Management Accounting Research, 14 (4): 361-388. https://doi.org/10.1016/j.mar.2003.10.001

Szabó, J., Farkas, S. (2011): A válság hatásai a magyar kis- és középvállalati szektorban. Vezetéstudomány, 42 (9): 29-39.

Trailer, J. W., Hill, R. C., Murphy, G. B. (1996): Measuring performance in entrepreneurship research. Journal of Business Research, 36 (1): 15-23. https://doi.org/10.1016/01482963(95)00159-X

Vorhies, D. W., Morgan, N. A. (2003): A Configuration Theory Assessment of Marketing Organization Fit with Business Strategy and Its Relationship with Marketing Performance. Journal of Marketing, 67 (1): 100-115. https://doi.org/10.1509/jmkg.67.1.100.18588

Wall, T. D., Michie, J., Patterson, M., Wood, S. J., Sheehan, M., Clegg, C. W., West, M. (2004): On The Validity Of Subjective Measures Of Company Performance. Personnel Psychology, 57 (1): 95-118. https://doi.org/10.1111/j.1744-6570.2004.tb02485.x

Waśniewski, P. (2017): A performance measurement system for small enterprises - a case study. Zeszyty Teoretyczne Rachunkowości, $93 \quad$ (149): 211-233. https://doi.org/10.5604/01.3001.0010.3197

Wu, D. (2009): Measuring Performance in Small and Medium Enterprises in the Information \& Communication Technology Industries. School of Management College of Business RMIT University.

Zéman, Z., Béhm, I. (2016): A pénzügyi menedzsment controll elemzési eszköztára. In: A pénzügyi menedzsment controll elemzési eszköztára. https://doi.org/10.1556/9789634540137

Zulkiffli, S. N. 'Atikah, Perera, N. (2011): A Literature Analysis on Business Performance for SMEs: Subjective or Objective Measures? SSRN Electronic Journal. 1-9. https://doi.org/10.2139/ssrn.1867874 